\title{
グルタミン酸脱水秦醭素の活性におよぼすトリエタノール アミンなどの影響*1
}

\author{
林 弘祐, 須原清治 \\ 名古屋大学医学部附属病院薬剤部*2

\begin{abstract}
Effects of Triethanolamine and Related Compounds on the Enzyme Activity of Glutamic Acid Dehydrogenase*1
\end{abstract}

\author{
HIROSUKE HAYASHI, and KIYOHARU SUHARA \\ Pharmacy of Nagoya University Hospital*2
}

(Received November 16, 1982)

\begin{abstract}
An investigation was attempted to determine the effects of triethanolamine, monoethanolamine, ammonium sulfate, hydrazine hydrate and hydroxylamine hydrochloride on the enzyme activity of glutamic acid dehydrogenase which is a pyridine enzyme playing an important role in the oxidation and reduction of living bodies. Results obtained were as follows :

1) Sodium glutamate and DPN were dissolved in a potassium phosphate buffer solution. Immediately after addition of the enzyme solution to the buffer, each of the above reagents in different concentrations was added to determine the effects of the mixtures on the enzyme activity for 6 minutes. Triethanolamine, monoethanolamine and hydrazine hydrate enhanced the enzyme activity. The largest increase, about $46 \%$, was observed in the monoethanolamine mixture at the final concentration of $3.3 \times 10^{-2} \mathrm{M}$. The second largest increase was found in triethanolamine and the smallest in hydrazine hydrate.

2) Hydroxylamine hydrochloride and ammonium sulfate inhibited the activity of glutamic acid dehydrogenase; ammonium sulfate inhibited the enzyme activity by about $50 \%$ at the final concentration of $5.0 \times 10^{-3} \mathrm{M}$, and the percentage was higher than that caused by hydroxylamine hydrochloride.
\end{abstract}

Keywords-glutamic acid dehydrogenase; diphosphopyridinenucleotide; enzyme reaction; enhancement of enzyme activity; triethanolamine; monoethanolamine; hydrazine hydrate; inhibition of enzyme activity; ammonium sulfate; hydroxylamine hydrochloride

医薬品は生体に適用され, 疾病の治療, 診断, 予防に 用いられるので, これの有効性, 安全性は重要となって くる.とくに最近, 医薬品の副作用が重要視され, 医薬 品の安全性が叫ばれるようになった. 現在用いられてい る医薬品あるいは医薬品添加物についても, 現時点にお いてその使用量以内では生体に対する安全性が認められ ており，まるごとの生体についての影響は考えられなく ても，その生体の酵素レベルにこれら医薬品，医薬品添 加物がどのような影響をあたえるか，また，これが長期 投与によって問題が起こることも考えられる．とくに近

*1 日本薬学会菓海支部病薬例会（岐皁, 1977年) で 発表.

*2 名古屋市昭和区鶴舞町65；65, Tsurumai-cho, Showa-ku, Nagoya, 466 Japan
年, 医薬品の相互作用に拈いて, ある医薬品が生体の酵 素誘導, あるいは酵素阻害によって, 他の併用医薬品の 作用に影響をあたえることによる投与医薬品の薬効の減 弱あるいは副作用の発現 ${ }^{1,2)}$ が問題となっており，医薬 品の生体内酵素におよぼす影響もクローズアップされて きた.

著者らはこの点に着目し, 医薬品およびその他の添加 物が生体内酵素の酵素活性におよぼす影響について検討 し, 若干の知見を得たので報告する。

\section{実 験 の 部}

\section{1. 実験材料}

近年, 抗生物質などが広く用いられるようになり，こ れに伴いビタミンとくにビタミン $\mathrm{B}_{1}, \mathrm{~B}_{2}$ の欠乏による副 
作用が報告され,34) このビタミン欠乏症はいわゆるアリ ボフラビノージスないしペラグラ様症状といわれてい $ろ^{5,8)}$ が，これは抗生物質がフラビン酵素におよぼす阻 害作用による問題と考えられている。しかし，同じビタ ミンB群で抗ペラグラ・ビタミンであるニコチン酸フミ ドの誘導体を補酵素とするピリジン酵素におよぼす医薬 品の影響はあまり報告されていなく，わずかに八木7ら ら の報告があるのみであるので, 今回著者らはニュチン酸 アミドの誘導体 diphospho-pyridine-nucleotide を補醉 素とし, 生体の酸化・還元, すなわち生体内の水素の伝 達に重要な役割をはたすピリジン酵素のらちの一つであ
るグルタミン酸脱水素酵素を用い，これの酵素活性にお よ注す影䈏について検討した。

グルタミン酸脱水素酵素アポ酵素は久保ら ${ }^{8)}$ の方法に したがい，Fig.1に示す方法により調製し，これを0.05 Mリン酸カリウム緩衝液 (pH 7.6) に溶解したものを0.2 $\mathrm{ml}$ 用いた。八木ら゙)はこのグルタミン酸脱水素酵素の酵 素活性にビタミン $\mathrm{B}_{2}$ の溶解補助剂として用いられている ニコチン酸アミドが阻害することを報告しているので, われわれも溶解補助剤として用いられているトリエタノ ールアミン，モノェタノールフミン，さらに硫酸フン モニウム, ヒドロキシルアミン, 抱水ヒドラチンなど

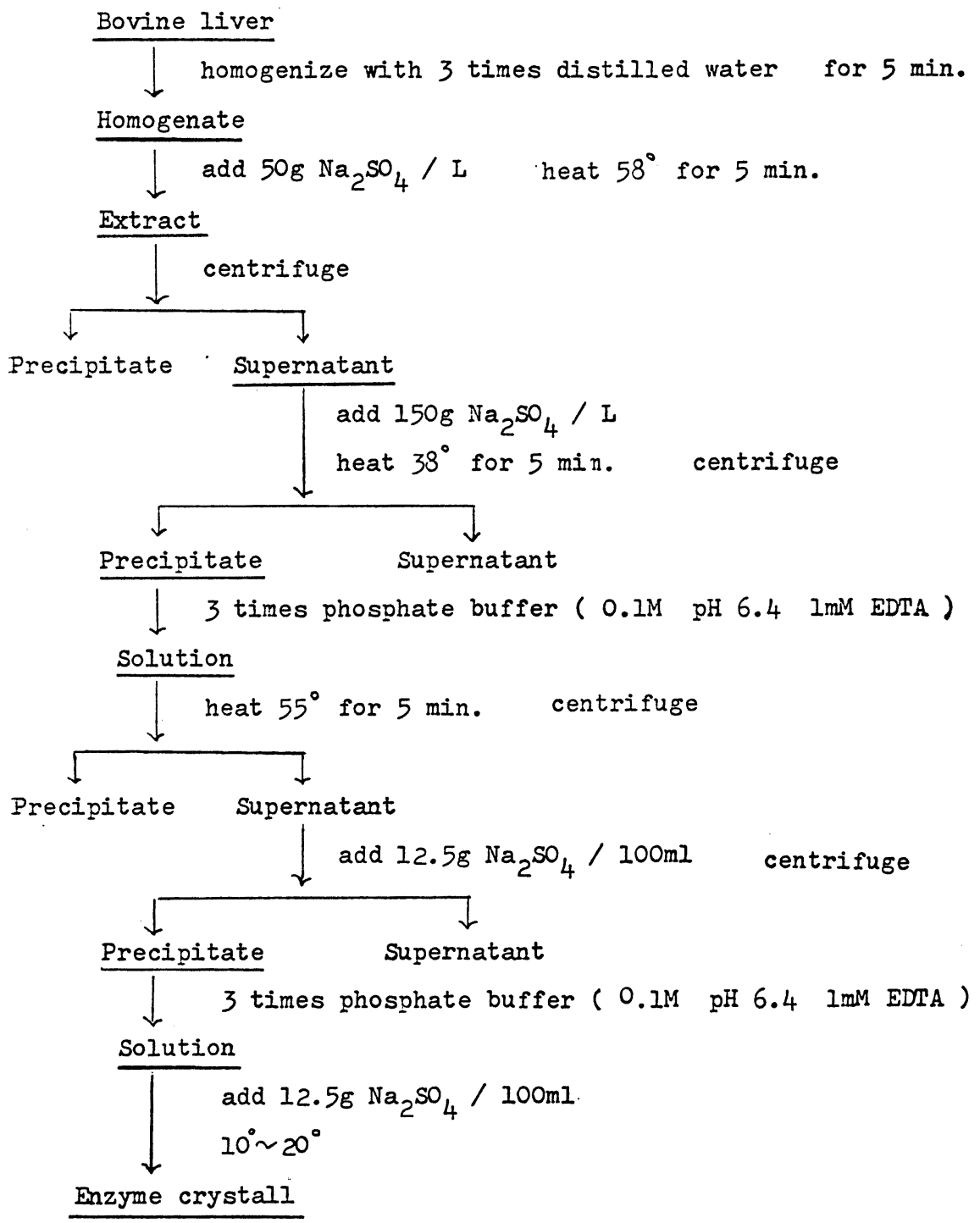

Fig. 1. Procedure of Glutamic Acid Dehydrogenase 
Table 1. Samples Used in This Experiment

Nicotinamide<smiles>NC(=O)c1cccnc1</smiles>

Triethanolamine

Monoethanol amine

Ammonium Sulfate

Hydroxylamine Hydrochloride

Hydrazine Hydrate
$\mathrm{N}\left(\mathrm{CH}_{2} \cdot \mathrm{CH}_{2} \cdot \mathrm{OH}\right)_{3}$

$\mathrm{H}_{2} \mathrm{~N} \cdot \mathrm{CH}_{2} \cdot \mathrm{CH}_{2} \cdot \mathrm{OH}$

$\left(\mathrm{NH}_{4}\right)_{2} \mathrm{SO}_{4}$

$\mathrm{NH}_{2} \cdot \mathrm{OH}-\mathrm{HCl}$

$\mathrm{NH}_{2} \cdot \mathrm{NH}_{2}-\mathrm{H}_{2} \mathrm{O}$
Table 1 に示したよらに，アミンを中心に医薬品および その他の添加物として用いられている化合物について， これがグルタミン酸脱水素酵素の活性にどのような影暗 をあたえるかを検討した。

Diphospho-pyridine-nucleotide (以後 DPN と略す) はクルタミン酸脱水素酵素の補酵素であるが，これは California Foundation 製のナトリウム塩を精製水で 3 $\mathrm{mM}$ の濃度に溶解して用いた。

グルタミン酸ナトリウム, 基質としてのグルタミン酸 ナトリウムは市販試薬の結晶を精製水に溶解し, $0.5 \mathrm{M}$ の濃度とした。

2. 实的方法

1) 酵素活性の測定法

クルタミン酸脱水素酵素は基質から水素を離脱し，そ の水素を DPN に与え DPN はDPNH となる. Fig. 2 に示すように, DPN は260nm において著しい吸収帯を 持っているが, DPNH となると 260nm における吸収帯 はわずかに減少し，340nmのところに新たな吸収帯があ らわれてくる.9) したがって DPN $\rightarrow$ DPNH に変化する
Table 2. The Systems of Enzyme Reaction

\begin{tabular}{l|c|c|c}
\hline \hline & 1 & 2 & 3 \\
\hline $0.5 \mathrm{M}$ Sodium Glutamate & $\begin{array}{c}(\mathrm{ml}) \\
-\end{array}$ & $\begin{array}{c}(\mathrm{ml}) \\
0.2\end{array}$ & $\begin{array}{c}(\mathrm{ml}) \\
0.2\end{array}$ \\
\hline $3 \mathrm{mM} \mathrm{D} \mathrm{P} \mathrm{N}$ & 0.1 & 0.1 & 0.1 \\
\hline Enzyme Solution & 0.2 & 0.2 & 0.2 \\
$0.5 \mathrm{M}$ Phosphate Buffer & 3.7 & 3.5 & 3.3 \\
Sample & - & - & 0.2 \\
\hline
\end{tabular}

と $340 \mathrm{~nm}$ での吸光度が当然変化してくるので, 定めら れた測定条件の下に拈いて吸光度が変化する割合は酵素 活性に直接依存しており，一般に脱水素酵素の酵素単位 は 1 分間に $340 \mathrm{~nm}$ での吸光度の 0.001 の変化として定 義されている.10)

著者らはグルタミン酸脱水素酵素の酵素活性と Table 1 の被検物が酵素におよぼす影響を検討するため，Table 2 に示すような酵素反応系を用いた. 基質グルタミ ン酸ナトリウム, 補酵素 DPN をリン酸カリウム緩衝液 に溶解し, 分光光度計の $10 \mathrm{~mm}$ 七ル中に入れ, 酵素液 $0.2 \mathrm{ml}$ を添加後すみやかに摫汼して $340 \mathrm{~nm}$ の吸光度の 変化を 1 分ごとに 6 分間測定し酵素活性を求めた．同様 にリン酸カリウム緩衝液 $0.2 \mathrm{ml}$ のかわりに被検物を所定 濃度より倍数希釈したものを $0.2 \mathrm{ml}$ 加えよく摫汼後, 10 分間放置して, 平衡に達してから酵素液を $0.2 \mathrm{ml}$ 添加し て 1 分毎の $340 \mathrm{~nm}$ の吸光度を測定し, 被検物がグルタ ミン酸脱水素酵素の酵素活性におよぼす影響を検討し た.また，対照としてグルタミン酸ナトリウムあるいは 被検物を同量のリン酸カリウム緩衝液に置きかえたもの

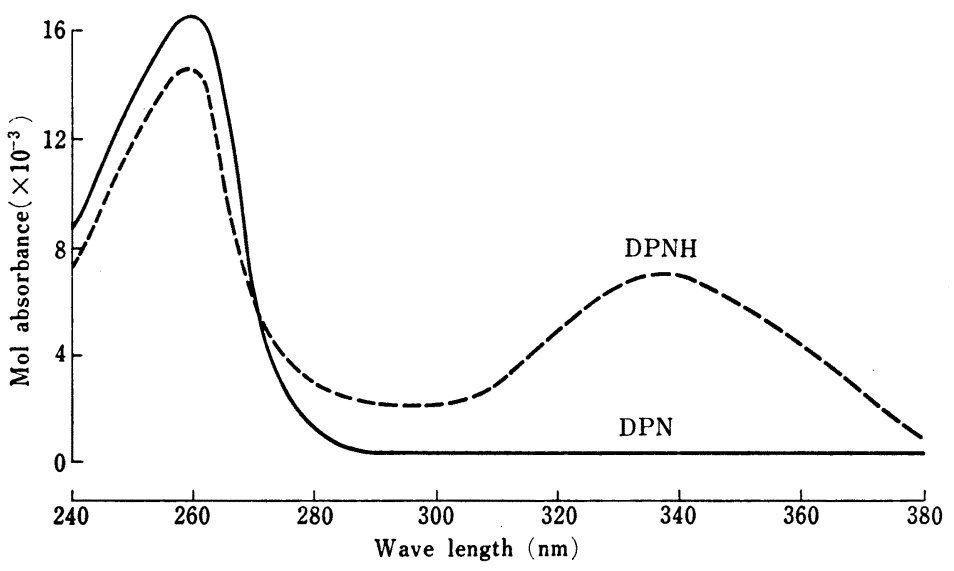

Fig. 2. The Absorption Spectrum of DPN and DPNH 
を同様に測定した。なお，本実験は室温 $20 \sim 25^{\circ} \mathrm{C} て ゙$ で った。

\section{実験結果と考察}

\section{1. グルタミン酸脱水秦䁖秦の活性化}

基質, 補酵素, グルタミン酸脱水素酵素による酵素反 応系に対し. 溶解補助剤として用いられているトリエタ ノールアミンを終濃度 (Table 2 の酵素反応系にお打る 全容積中の被検物のモル濃度, 以後これを終濃度と記 す）として $5.0 \times 10^{-2} \mathrm{M}$ から各 2 倍に倍数希釈したもの を添加した時の酵素活性におよぼす影響について Fig. 3 に示した。トリエタノールアミンはグルタミン酸脱水素 酵素の作用を活性化し，それはトリェタノールアミンの 添加濃度が高濃度になるにしたがい酵素活性化作用は大 となり, 終濃度 $5.0 \times 10^{-2} \mathrm{M}$ においては無添加に比し約 $34 \%$ 酵素作用を增強し, 本実験における最も低濃度の $1.25 \times 10^{-2} \mathrm{M}$ でも約 $8.4 \%$ 䣼素作用を活性化した。

モノェタノールアミン, 抱水ヒドラチンも同様にグル タミン酸脱水素酵素の酵素活性を Fig. 4,5 亿示すよう に增強した。モノェタノールアミンはグルタミン酸脱水 素酵素の活性化作用は最も強く, 終濃度 $3.3 \times 10^{-2} \mathrm{M}$ 亿 おいて約 $46 \%$ 酵素作用が增強し, 抱水ヒドラチンは前二 者に比しその活性化作用は弱く, 終濃度 $5.0 \times 10^{-2} \mathrm{M}$ に おいて約 $25.6 \%$ グルタミン酸脱水素酵素作用の增強を示 した。

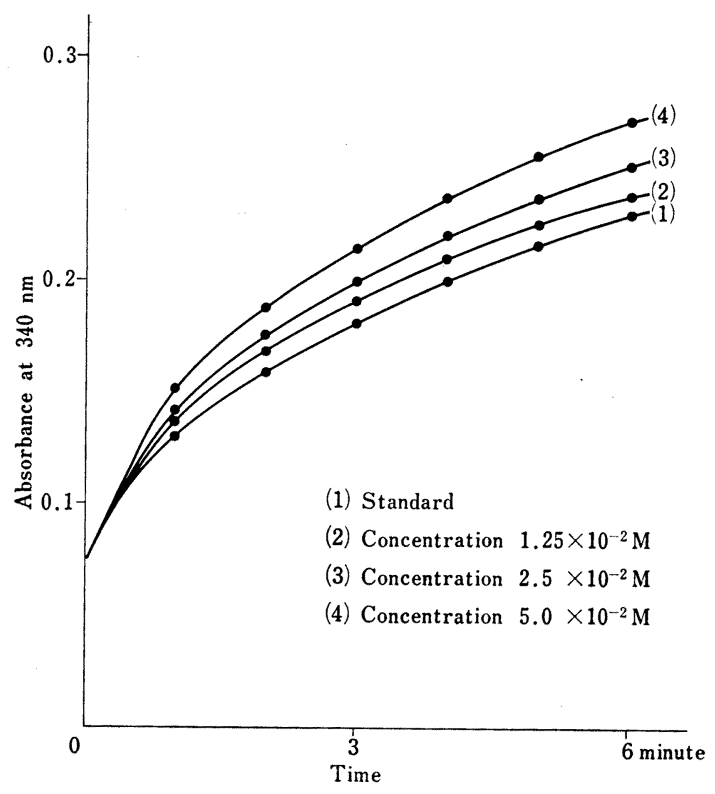

Fig. 3. Effect of Triethanolamine on Glutamic Acid Dehydrogenase

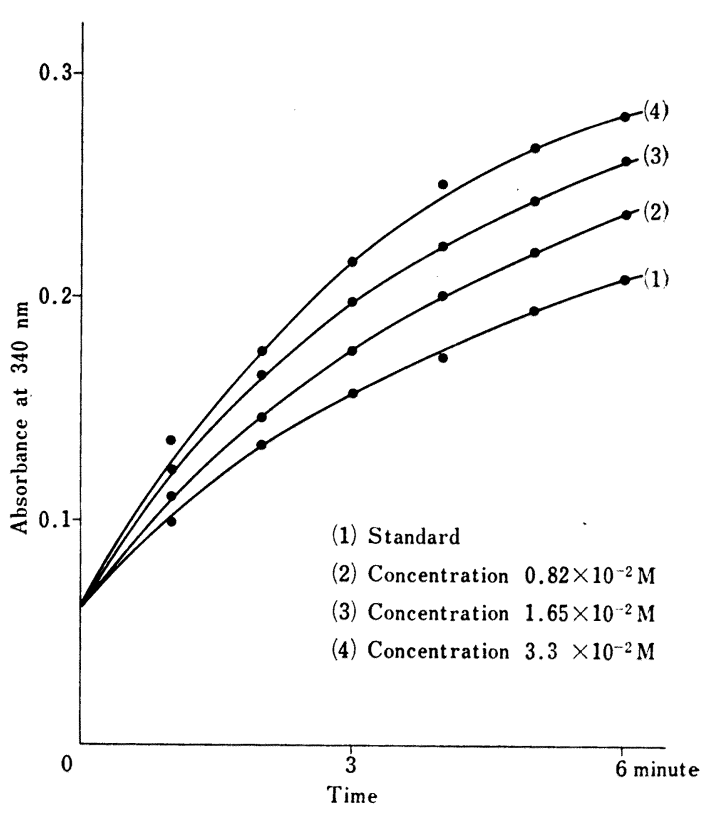

Fig. 4. Effect of Monoethanolamine on Glutamic Acid Dehydrogenase

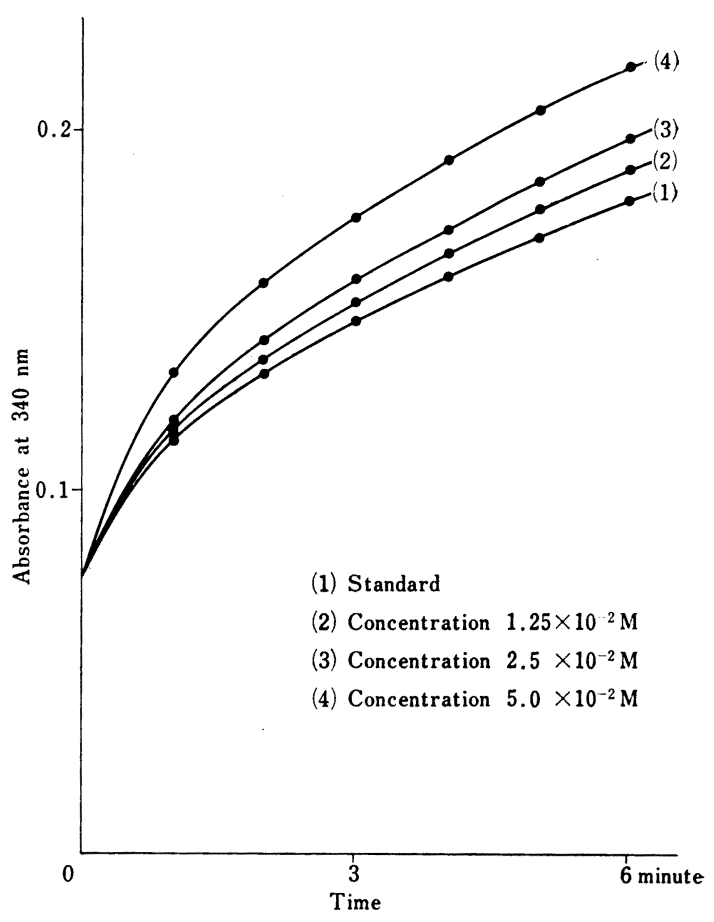

Fig. 5. Effect of Hydrazine Hydrate on Glutamic Acid Dehydrogenase 


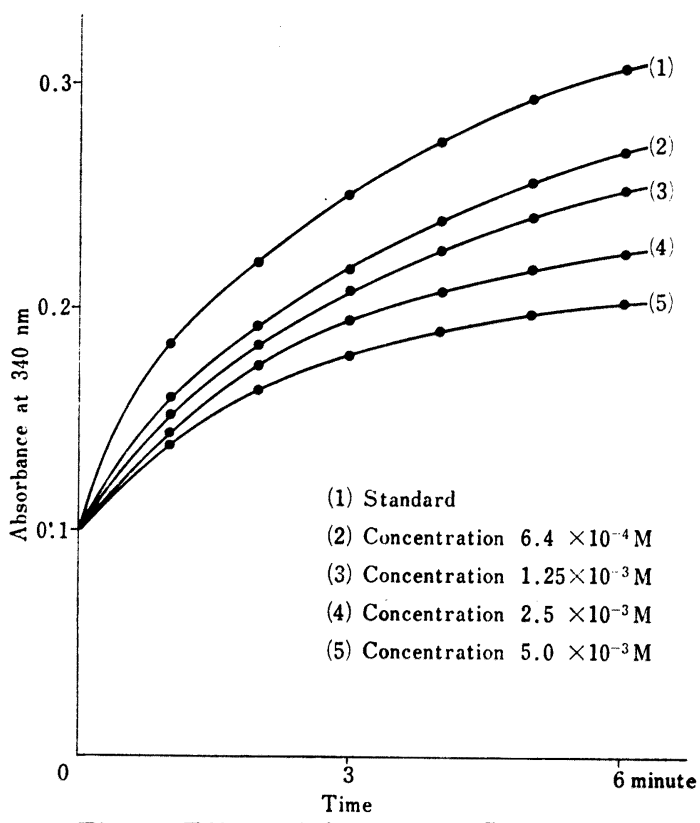

Fig. 6. Effect of Ammonium Sulfate on Glutamic Acid Dehydrogenase

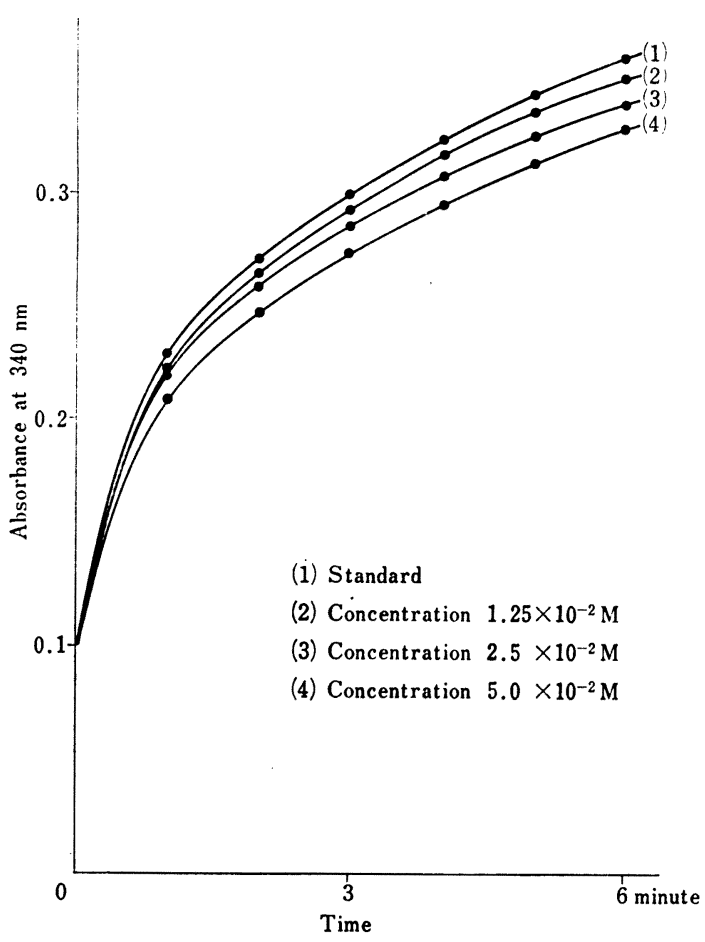

Fig. 7. Effect of Hydroxylamine Hydrochloride on Glutamic Acid Dehydrogenase

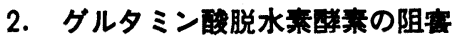

グルタミン酸脱水素酵素系に対し硫酸アンモニウム， ヒドロキシルアミンを添加した時, Fig. $6 ， 7$ に示した ようにその酵素活性を阻害, 減弱した. 硫酸アンモニウ ムはグルタミン酸脱水素酵素に対し,終濃度 $5.0 \times 10^{-3} \mathrm{M}$ より各 2 倍倍数希釈により添加した時，各濃度において 酵素作用を大きく阻害した。終濃度 $5.0 \times 10^{-3} \mathrm{M}$ におい て約 $50 \%$ ，本実験における最も低濃度 $6.4 \times 10^{-4} \mathrm{M}$ にお。 いても約 $16.8 \%$ ルタミン酸脱水素酵素の活性を阻害し た.

ヒドロキシルアミンも同様にグルタミン酸脱水素酵素 の活性を阻害したが, 硫酸アンモニウムよりその阻害作 用は弱く,硫酸アンモニウムの10倍に近い濃度 $5.0 \times 10^{-2}$ Mでも約13.3\%酵素活性を低下させたのみである.

以上のようにグルタミン酸脱水素酵素の酵素反応系に トリエタノールアミンなど医薬品その他の添加物を加え た時, トリエタノールアミン，モノェタノールアミン， 抱水ヒドラチンの順でグルタミン酸脱水素酵素の活性を 増強し, 硫酸アンモニウム, 次いでヒドロキシルアミン が酵素作用を阻害した。

最近, 医薬品の相互作用に括いて生体内酵素の誘導, 阻害による副作用, 薬効の減弱がいわれているが，この ような肝ミクロゾームに括ける薬物代謝酵素量を増加さ せる酵素誘導や生体の各藏器などの作用点あるいは受容 体への競い合い阻害など生体レベルによる作用以外に る, in vitro に打ける酵素, 補酵素, 基質による酵素反 応系に直接およぼす阻害, 活性化作用により酵素作用を 変化し, それによる生体への影響も考えられる. しかし 実際には医楽品その他の添加剤を生体に適用した時, こ れらの物質がこのような高濃度に生体内酵素に接触する とも考えにくく, また, 決められている使用量以内にお いてはとくに副作用についても閴にしなくてもよいか も知れないが, 長期にわたる使用, 高濃度による生体内 酵素に対する影響，さらにそれらによる生体への副作用 についても無視することはできないと考える.

\section{結 論}

生体内に拈ける酸化・還元, すなわち水素の伝達に重 要な役割をはたすピリジン酵素の一つであるグルタミン 酸脱水素酵素の酵素活性について, 医薬品の溶解補助剤 であるトリェタノールアミン，モノェタノールアミンな ど医薬品その他の添加物, 硫酸アンモニウム, ヒドロキ シルアミン, 抱水ヒドラチンなどアミンを中心にこれら 化合物がどのような影響をおよぼすかについて検討し， 次の結果を得た。 
1. グルタミン酸ナトリウム，DPNをリン酸カリウ ム緩衝液に溶解し, これにグルタミン酸脱水素酵素液を 添加, この酵素活性について前記各化合物の所定濃度に 希釈したものを加え， 6 分間の醭素活性におよぼす影響 を測定したところ，トリェタノールアミン，モノェター ルアミン, 抱水ヒドラチンがグルタミン酸脱水素酵素の 作用を増強した。これらのうちではモノェタノールアミ ンが終濃度 $3.3 \times 10^{-2} \mathrm{M}$ とおいて無添加に比し約 $46 \%$ 酵 素活性を増強し, 最も醅素活性の増強が大であった. 次 いでトリェタノールアミン, 最も酔素活性の增強作用が 少なかったものは抱水ヒドラチンであった.

2. グルタミン酸脱水素酵素の酵素活性を阻害したも のはヒドロキシルアミン, 硫酸フンモニウムであり, 硫 酸アンモニウムは終濃度 $5.0 \times 10^{-3} \mathrm{M}$ において約 $50 \%$ グ ルタミン酸脱水素酵素の活性を阻害し，それはヒドロキ シルアミンの酵素活性阻害作用よりはるかに大であっ た。

\section{交}

獸

1) W. D. Diamond, R. A. Buchanan : J. Clin. Pharmacol., 10, 306 (1970).

2) J. Christiansen, M. Dam : Acta Neurol Scand., 49, 543 (1973).

3) R. L. Brown : Arch. Otolaryng., 45, 35 (1947).

4) H. J. Harris : J. Am. Med. Assoc., 142, 161 (1950).

5）青山進午，岸川基明，㐘地三郎，获谷徹，長谷川 栄一, 藤原洋一, 伊藤吉夫, 水谷広治, 山田己年 夫，八木国夫：日本医事新報，1606，24 (1955).

6) K. Yagi, J. Okuda, T. Ozawa, K. Okada : Science, 124, 273 (1956).

7) 八木国夫，八木鉱文：生化学，32，53 (1960).

8) H. Kubo, T. Yamano, M. Iwatsubo, H. Watari, T. Soyama, J. Shiraishi, S. Sawada, N. Kawashima, S. Mitani, K. Ito : Bull. Soc. Chim. Biol., XL, 431 (1958).

9）江上不二夫編 : “標準生化学 実験法,”文光堂, 1953 , p. 301.

10）三浦義彰監訳：“ハーパー・生化学,”丸善, 1980, p. 58 . 